\title{
Potential Food Crop Production and Food Security in Kampar regency of Riau Province
}

\author{
B. Isyandi \\ Faculty of Economics, University of Riau \\ bernard.isyandi@gmail.com
}

\begin{abstract}
Objectives of this study is to determine the economic and social benefits in building a regional scale of agricultural economy and influence over the land in relation to the development of food security and economic. This study was conducted through a survey method in Kampar District of Riau Province. The variables measured are determinants of crop production and food security. The results found that the area is faced with a decline in the production of rice and pulses which have an impact on rice shortage which was also caused by the potential not yet optimal management of land resources as a whole. The result showed that agricultural land, the number of seeds, fertilizers, insecticides and labor, both partialy and simultaneously, effect the food security in Kampar District.
\end{abstract}

Keywords: agriculture development, production economic, food security.

\section{INTRODUCTION}

Foreign food products are now flooding the domestic economy, although there is an increase in production but they have not been able to pursue required amount of food in the country. This is due to the relatively stagnant of productivity and land area which is not even increasing rapidly due to land conversion. In addition, the land conditions are not more fertile land due to dependence on chemical fertilizers, no less important government policy (regions) that have not sided with the farmers. Government policies (regional) make the agricultural products even worse. For example, during a shortage of food needs, government has always issued a policy of food imports. This shows that the government's impartiality on food producers is weak. As a result, there is no prosperous farmers. Theoretically, it can be concluded that imported food that lasts long is very dangerous for the life of the nation. In this world there are countries which rely foodstuffs on other nations, because life and death of nations depends on foodstuffs.

Basically, there are two main factors that cause many imported agricultural products flooding the market, the first increase in a population of 1.49 percent (in 2025 will be equal to 273.2 million), increasing residents would need food (accompanied by the growing middle income group); both democracy and reform positively impact the asset-economic decentralization; Besides economic growth above 5.5 percent of total income residents, causing lower income classes moved higher income or increasing the number of middle class so that the demand for food also increased (CBS, 2013). Product is inadequate while the demand and purchasing power increases, food needs are supplied from abroad;

Related to the ecological disasters that often occured in the last five years, the main objectives of national development to improve the welfare of the people through poverty reduction is paradox. Increasingly deteriorating environmental balance reflects the failure to achieve the main purpose of the Millennium Development Goals or MDGs (Isyandi, 2005). One of the eight millennium development goals is to integrate the principles of sustainable development into national development and rehabilitation of damaged natural resources. This cannot be realized due to the pressure of natural disasters such as floods, forest-land fires, smog, air pollution, pollution of rivers and the sea, the mountain erupted, and so on. This brought much concerns from most countries in the world to save the environment, especially in maintaining the availability of food.

Food security is the state achieved when food systems operate such as that all people, at all times, have physical and economic access to sufficient, safe and nutritious food to meet their dietary needs and food preferences for an active and healthy life (FAO in CGIAR, 2009). Du Toit, et .al. (2011) states that the concept of food security is closely related and linked with the poverty in country. The two concepts are interrelated and to some extent have an influence on one another. In any food security discourse it also 
essential to highlight a nutshell the plight of poverty in the country. Essex (2010) states that food security as the way explaining chronic hunger and more extreme famine events in the absence of food availability deficits, and highlighting the complexity of food outcomes in varied social, economic, political and environmental conditions.

Food security is the availability of food and one's ability to access it. A household is said to have food security if the occupants are not in starving conditions or threatened with starving. Food security is a measure of interest to the disorder in the future or lack of essential food supplies due to various factors such as drought, disruption of distribution, fuel shortages, economic instability, war, etc.

Food security assessment is divided into individual self-reliance and external dependency which divides the set of risk factors. Even though many countries wanted individual self-sufficiency to avoid the risk of failure of transport, it is difficult to achieve in developed countries. It is because the jobs that are very diverse and the high cost of food production if not industrialized. Conversely, high individual selfsufficiency without sufficient economy will create a society prone to production. Food availability related to the food supply includes production, distribution, and exchange.

Production of food is defined by a variety of factors, including land ownership and use; type and soil management; the selection, breeding, and management of agricultural crops. The production of agricultural crops can be affected by changes in temperature and precipitation. The use of land, water, and energy to grow food often compete with other needs. Use of land for agriculture can be turned into residential or lost due to desertification, salinization and soil erosion due to unsustainable agricultural practices.

Efforts to develop food security are not only related to the technical aspects of the adequacy of food supply but also to the aspects of purchasing power (household income community), holding development, especially to those related to health (build awareness for the consumption of energy and protein in sufficient and safety of food consumed), and conservation of natural resources associated with the ability of producing materials food locally in the area to fulfill part or all of the requirements.

Considering the important of food security development at various levels (ranging from family, village, district, provincial and national), government has already released and issued the Decree no. 4/ 1996 (Undang-undang Nomor 7/1996) relating and concerning of food. The law states that the government and the local government should stricly organize setting, guidance, control and supervision under food security. Meanwhile the community should also organize production processes and supply, trading and distribution and as consumers who entitled to obtain adequate, safe, nutritious and affordable food to their purchasing power.

In order to build food security conditions much higher, a direction and framework are required. These can be the basis to manage various aspects of food security such as the development of systems of production, distribution and marketing, diversification, oversight of food safety and consumer sufficient condition to facilitate developing physical qualities of human resources. It means that building food security has many dimensions and involves many parties that there should be a policy that became the basis for synergistic interaction and coordination. As Illustration, spacious rice crop nationally, ranging from 13.5 million to 14 million hectares. National reserve of paddy's seed stocks reached 13,600 tons and can be planted in the area of 565,000 hectares, including seed stocks of corn and soybeans. Based on the data, the national of paddy's production plans in 2014, is targeted at 76 million tons of milled rice (GKG). Compared to the year 2013, it could reach 71.8 million tonnes of paddy. The target is indeed experiencing significant improvement. The development of agriculture is still the main focus of Indonesia's development to improve farm of productivity and value-added agricultural products to improve farm incomes (Mosher, 2000 in Isyandi, 2005).

The condition of food security in Riau province is currently facing the threat quite heavy (Gevisioner, 2014). Based on the analysis of food supply in 2013, it is concluded that the availability of food in the form of energy reaches 3,072 calories and consumption reached only 2,079 calories (Food Security Agency Riau, 2014). The increase of malnutrition prevalence and malnutrition among toddler indicate a decrease in household food security. In that year prevalence malnutrition reached 13.3 percent and 9\% for severe malnutrition (Ministry of Health, 2013). This condition will cause a decline in the quality of human resources, due to malnutrition which causes failure of physical growth and intellectual development, reduces productivity, lowers resistance, and increases morbidity and mortality (Sukandar, in Gevisioner, 2014). In the future, the problem of food supply in the province of Riau will possibly be quite serious, because of the high population growth, poverty, the degradation of the environment, the exchange rate of the rupiah, drought and land use. These changes will affect the production of various agricultural commodity crops, especially rice. On the other hand, the availability of food will be determined by the food production in this area. Considering that food needs in the province of Riau still have to be imported from other regions, the imports will also affect to the food prices which can fluctuate at any time. On one side, demand for food is rising, while the other side the availability of food is still limited. This situation will increase the food prices.

In agricultural development, food crops help to 
increase the income and standard of living of farmers. In additional, it also helps to increase agricultural production to meet food needs and improve the nutritional status of the population, through diversification of food items. Data is obtained through food consumption per capita rice consumption (divided by the population). The data showed that in 2012, rice consumption in Kampar regency has reached $91.10 \mathrm{~kg}$ per capita per year. Assuming the average growth of the population of Kampar regency of $4.86 \%$ per year, the estimated population of Kampar Regency in 2015 was as much as 882.861 people. The average requirement for commodities population is estimated at 67.352 tonnes of rice per year, or $76.3 \mathrm{~kg}$ per capita.

To increase the productivity and production, efficiency, added value and competitiveness, it needs to build a solid of food security. It first starts at the level of household which is based on the diversity of local resources. Therefore, the approach to strengthening food security is implemented by developing variety of food sources, institutional food, and food cultures in the communities in each region. In this case, it can be concluded that food security is the fulfillment of the conditions of food for every household that is reflected in the availability of adequate food, both in number and quality, safety, equitability, and affordability.

Master plan of Riau province in 2020, volume 1, shows that Kamper ranks at the high position based on the combined index food insecurity as well as the index of vulnerability to of starving. It means that the condition is not safe for food security. Other thing that matters is that if someone does not have enough cash, job, or low-wage earnings, then starving might be imminent. This condition affects the process of improvement of health status and nutritional status, particularly in the preparation of the future generation capacity because as much as $34.77 \%$ of the population is between the ages of 0-4 years old who depends on food security itself. Extracted from Kampar, there are three main characteristics of food-insecure communities; the poor, low education, and the main sources of income which is earned from agriculture.

Understanding the meaning and significance in the development of agriculture above, the authors make the formulation of the problem as followed:

(1) How are the geographical conditions, which determine the potential for crop lands as a factor of production in relation to food se curity in Kampar, Riau.

(2) How to determine land use agricultural production potential in crops in Kampar, Riau.

(3) What are the chances of (local) government in building food security in Kampar, Riau.

(4) How to educate the cropping pattern different types of crops, so that amount of production in Kampar, Riau increases.

(5) How to use the opportunities of cropland in Kampar, Riau.
(6) How are the conditions of the farm, the number of seeds, fertilizers, insecticides, and labor to food security in Kampar, Riau.

\section{METHOD}

A research activities conducted in Kampar regency, Riau province, Kampar district was chosen as the research object because the community in this area is mostly exploited the potential of land owned as crop production. There are various sources of data that can be collected by researchers. By viewing the original source, the data can be grouped and classified into two: primary and secondary data. Primary data is collected and done by the method of Rapid Rural Appraisal (RRA), which is a participatory approach to obtain data/ information and assessments in general in the field in a relatively short time. This method does not necessarily require a questionnaire. The questionnaire would only serve as a general guideline to remind researchers to not deviate from the purpose of research. Descriptive statistical analysis is used to describe or provide an overview the object to be studied through the data sample or population as they make and apply conclusions to the public (Sugiyono, 2009). Thus the descriptive statistical analysis in this study is used to provide an overview of related variables. The use of descriptive statistics in this study is to provide a description of the independent and dependent variables through the use of a frequency table. Inferential analysis is used for the quantitative data collected. In analyzing the data on all the information collected, the authors use the method of multiple linear regression analysis. The analytical method used is the analysis method of Cobb Douglas on production function, because this method is often solved by using multiple regression or simple regression. Cobb Douglas formed the formula of a multiple regression equation (Multiple linear regression) as followed:

$$
\begin{gathered}
\operatorname{Ln} Y=\operatorname{Ln} \beta_{0}+\beta_{1} \operatorname{Ln} X_{1}+\beta_{2} \operatorname{Ln} X_{2}+\beta_{3} \operatorname{Ln} X_{3}+\beta_{4} \\
\operatorname{Ln} X_{4}+\beta_{5} \operatorname{Ln} X_{5}+e
\end{gathered}
$$

Requirement:

$\mathrm{Y}=$ Production per crop per year

$\beta_{0} \quad=$ Constant

$\mathrm{X}_{1}=$ Agricultural Land unit hectares $(\mathrm{Ha})$

$\mathrm{X}_{2} \quad=$ Number of seedlings unit packs

$\mathrm{X}_{3}=$ Fertilizer natural and artificial fertilizers unit $\mathrm{Kg}$

$\mathrm{X}_{4} \quad=$ Insecticides liter unit

$\mathrm{X}_{5} \quad=$ labor unit people

$\mathrm{e} \quad=$ Interference stochastic or measurement error;

Qualitative analysis is also conducted through primary and secondary data obtained from the interviews to policy makers (government bureaucracy) in the region and on the respondent. Based on quantitative and qualitative analysis above, it will then be formulated into 
a map of the potential for crop production in relation to Food Security in Kampar regency, Riau province.

\section{RESULT}

The geography of Kampar Regency are viewed as potential land for agricultural development. Agricultural sector contribution to the GDP of Riau province reached 46.68\% (Isyandi, 2007). Nonetheless, Kampar is still confronted by a decline in the production of paddy and pulses which have an impact on of shortage. This is caused by the potential which has not been optimal management of land resources as a whole. Therefore the agricultural development policy of both wet-land and dry-land must be adapted to the paradigm of agricultural development and revitalization functions supported synergistically to develop a network of agri-food crops and horticulture in Kampar Kiri Hilir, Central Kampar Kiri, Mount Sahilan, Tapung Hilir and Bangkinang. Seeing the comparison, wetlands has been utilized with various crops and also been used quite spacious, which is about 65 percent. Meanwhile, dry-land has not been utilized by 35 percent (CBS, 2013).

In addition to having the potential paddy field, Kampar District also has the potential of drylands, where most of them are larger extent than the potential of existing paddy field. In 2010, the area of dry land in Kampar regency was 197.346 ha (hectare) which can be used for crops covering an area of 63.615 hectares, while the rest of them is used for development of fruits. Potential dry land in Kampar regency is quite extensive, some of which are already used by communities to live their daily lives. Nonetheless, there are still many untapped dry land, mainly in District Tapung Hulu and Tapung Hilir. Seeing the percentage of untapped utilization and on dry land area, it is amounted to 48 percent of dry land utilized, while the remaining 52 percent has not been exploited. This condition would increase based on the amount of production of the commodities that were planted by the community (BPS 2013).

As an agricultural area which has the potential wetland and wide dryland, either already or untapped, Kampar continually strive to cover the various needs of the community. Along with the number of people who continues to increase each year, it is also followed by an increase in the number of food needs. It is not followed by an increase in the production of food crops and horticulture, therefore in 2010 Kampar had deficit of paddy.

With the addition of the total population in 2010 , the demand for rice in Kampar regency also increased for approximately 75669.11 tons, while rice production is only 62535.5142899 .36 tons which is equal to tons of rice. This situation has caused a deficit of Kampar regency on rice needs as much as 32769.75 tons or $40.31 \%$. However, compared to the previous year when the deficit needs rice was by $50.22 \%$, it showed that an increase in rice production is high enough therefore the production of rice is in the lower deficit. Otherwise, such food, like nuts, are in a deficit of about 5331.12 tons or $68.77 \%$. Food productions which have exceeded demand are tubers, fruits, vegetables and maize (BPS 2013).

Efforts to increase the number of rice production is by expanding the area of a planting. These conditions are about to be done because there are many areas which have not been utilized, such as in Sub Mine, where the total area of untapped is about 1,015 Ha. However, some farmers do not want to make the effort to expand the planting area. In 2010, the field of paddy's a planting in Kampar regency is 16.487 ha comprising an area of 11.173 ha of paddy and upland rice area of 5314 ha. Harvested area of rice is 15.316 ha comprising of 10.088 ha of paddy rice with a productivity of 4.76 tonnes/ ha and 5,228 ha of upland rice with a productivity of 2.78 tonnes / ha. From the planting area, not everything can be harvested, because some plants have failed / corrupted which is 30 ha which comprised of 2 ha of rice paddy and upland rice area of 28 ha. Although some vacant lands have already been planted by a wide variety of crop, but in reality not all of these plants can be harvested. This is due to some kind of crop damage / failure caused by a variety of factors, including pests, lack of fertilizer, or crops damage caused by flood.

Kampar regency is one of regencies in Riau Province which is famous for its fruits outcome. Ten years ago, Kampar District was the largest producer of citrus in the province of Riau. The production always continued regularly and citrus alwyas dominated the trading in the province of Riau. However, it is a bit different right now. All have rapidly changed and it is a bit difficult for the production to produce it for local consumption. Therefore, citrus sold in fruit market is either always imported or from outside the province of Riau. There are many factors caused the production of citrus fruits decreased Kampar, including soil fertility.

Oranges are not the only fruit products produced by Kampar. There are types of fruits that can be used as leading commodities by Kampar, including durian and pineapple. In additional, there are also other fruits planted by the community, in the level of household. The fruits are rambutan, mango, mangosteen, guava, jackfruit and banana. Viewing from the not-too-high production of those fruits, these plants have been able to help the farmers to support the needs of their daily lives. The total production cannot be separated from the number of trees planted by each farmer. Pineapple crops in District Tambang are the highest number in planting, about 7,147,326 trees or 98.94 percent of the total number of pineapple plants in Kampar regency. Meanwhile, durian ranks the second, which is about 131.787 trees. District XIII Koto Kampar is the district where most of durian trees are planted. It is about 34.779 
trees or 26.39 percent of the total (BPS, a few years of publication. Kampar in the figure

Pineapple plants is not only for sales in Pekanbaru (the capital of Riau Province), but also in other province, such as West Sumatera. The texture of soil in District Tambang are very suitable for pineapple plants. Pineapple grows very well in the peaty soil, as some land located in the District Tambang. Pineapples from the District Tambang (Rimbo Panjang) are sweet and have become the typical souvenirs of Kampar.

In effort to utilize pineapple in the District Tambang, Local Government in the last few years has conducted to coach society to make pineapple chips as the typical of Kampar because the production of pineapples District of Tambang is quite large. Although it is still in the scale of home-industry, the production is quite promising, especially for the local community. The chips are attractively packed and have been marketed in several shops selling traditional foods in Pekanbaru. Some guests from Jakarta or other cities in Indonesia, are keen to eat typical food of Kampar. Right now, Kampar chips are very well-known, both in Indonesia and other coutries. To promote this traditional food of Kampar to a higher level, it needs the cooperation of various stakeholders.

Pineapple chips are not the only community of Kampar refined products. Kampar also have of jackfruit chips, which is promising in terms of sales. Although it is still in the scale of home industry, the condition has made people of Kampar, particularly located in District Tambang, to produce of jackfruit chips. We can see from the results of jackfruit chips products that already marketed. There are still plenty to be reinnovate. This might be a bit compelling, but in terms of the appearance, the chips is not quite interesting. Many of of jackfruit chips are colored black which will reduce consumer tastes. They should find the way to make Jackfruit Chips more attractive and also can last longer in packs.

The agricultural sector is a sector which has an important role in overcoming the problem of poverty in Kampar. This is aligned with the statement of World Bank stating that food security, poverty reduction and economic development are inter-related and depend critically on improvements in agriculture. They require strategies that focus on increasing food productivity and incomes among small-scale farmers and access to income and employment for rural poor people who lack access to land (Mehra and Mary, 2008). Many activities can be done by the people of this sector, not only planting rice and other crops, fruits but also planting vegetables by utilizing a narrow area though. Seeing from the location of Kampar district, it is very close to the provincial capital. Farmers in Kampar basically have great opportunity to fill the demand for vegetables in the city of Pekanbaru. Even if there is a good marketing management to the production of these vegetables, it is not impossible vegetables from Kampar to dominate Singapore, due to the fairly close geographic position.

There are various types of vegetables which are planted by farmers in Kampar, such as beans, large chilli, cayenne pepper, cucumber, eggplant, kale, spinach, and others. But nobody can deny that the vegetables are still unable to compete with the production from the neighbor province of West Sumatera. Most types of vegetables sold in Pekanbaru are from West Sumatra, such as chili, cabbage and others. Although the value of economic sale of vegetables is quite high, it is also extremely helpful for the economic community (Isyandi, et al., 2007).

There are several factors that cause this condition occurs. The first one is the limited farmers. The area used for planting vegetables is still on a small scale. This condition is worsening by planting vegetables instead of the main occupation of farmers, but it is a side job. Therefore, they are not fully focused to keep and care on the vegetables they planted, but for something else. Another problem is the existence of various types of vegetables that require special treatment, such as high soil humus, moist weather conditions to be able to produce to the maximum (Isyandi, et al., 2007).

Seen from the planted area of each vegetable in 2010 in Kampar, it was still very small compared to the existing average. As for beans, the average is about 576 ha, cayenne is 165 ha, 586 ha of cucumber, 473 Ha of eggplant, $457 \mathrm{Ha}$ of kale, and 14 ha of cabbage. Compared to each districts with a population, the acreage of each type of vegetable is still very small. To plant beans, east district of Kampar has the most extensive acreage, which is $113 \mathrm{Ha}$. However, compared to the number of people in the township, an area of $113 \mathrm{Ha}$ is certainly not possible for people to get the optimal results. Therefore, the area of planting is still relatively very small even though with a highest and greatest plant of chili. Although the need of chilli is immense, in 2010, the acreage of Chilli in Kampar Kiri Hulu was only $1 \mathrm{Ha}$. This situation illustrated that community Kampar Kiri Hulu not only plants chilies merely to domestic use only, but also economic purposes. Likewise, other vegetables are consumed only for their own. For that, we need the attention from the various parties to Kampar regency could be one of the producers of vegetables in Riau Province (BPS, a few years of publication, Kampar in the figure).

Food security is an important element from the national security in the economic field, relating to food availability, affordability, consumption, security, and sustainability of supply. On the production side, agricultural development policies are applied during this more oriented towards the production target in the short and medium term including through the intensification of monoculture farming with the input of fertilizers and synthetic pesticides which are high and the use of 
seeds that have a high response to the input of water and fertilizer. Actual production issue cannot be separated from the human effort that aims to reach the requirement through actions and deeds. Thus, the production is not only an act of human to achieve the level of need, but the creation of objects or services that always direct services to meet the needs of human life.

Actually farming is not only confined to harvesting, but actually also the business of production. Here claims the ongoing utilization of land, capital, labor, and management / skill. Success in this utilization will then bring the results that can be retrieved. The quality and quantity will depend on the results of the processing, if the processing takes place from the beginning to capture the results that will be very satisfying producers. The production function outlines the ways how the inputs can be combined to generate number of products that have been planned, meaning that the technical relationship between the input alignment is in accordance with the product. Thus in the absence of inputs, the production is not going to take place and the planned production will not occur. In order to generate given level of output, it would be used comparison of the various mix of inputs which in this case will be determined by the most economic, effective, and efficient inputs (factors of production).

Changing the number of an input (factors of production), such as changes in labor, while other inputs unchanged or fixed, will bring effect on production, which may lead to an increase in the product. However, the increase in production will not always be guaranteed by the change in the amount of one of these inputs, eg labor with the law of diminishing returns (The Law of Diminishing Returns), which mean that reaching a certain level of increase in production will decline, eventually reaching the point negative. Such circumstances led to an increase in total production which has been slower. The results showed that agricultural land, the number of seeds, fertilizers, insecticides, and labor simultaneously affect the food security in Kampar regency. Statistic calculations obtained by the regression coefficients for the variables of agricultural land $\left(\mathrm{X}_{\mathrm{I}}\right)$ of 0.333 with a significance level of 0.008 . It means it is true that agricultural land variables have a significant effect on the food security at the $95 \%$ of confidence level. Likewise, for the regression coefficient variable number of seeds $\left(\mathrm{X}_{2}\right)$ is 0.368 with a significance level of 0.001 ; so it is true that a variable number of seeds have a significant impact on food security at the $95 \%$ of confidence level. Furthermore, the regression coefficients for the variables fertilizers $\left(\mathrm{X}_{3}\right)$ of 0.297 with a significance level of 0.003 ; it indicates that the fertilizer variables also have a significant influence on food security at the $95 \%$ of confidence level., and finally reaches the maximum level (optimum point) which also can further decrease.

Allotment of land in Kampar regency stated about regional spatial planning (RTRW). Comprehensive land use is translated in a spacious function area that consists of spacious function on protected areas and cultivated area which are calculated digitally appropriate regional criteria. The extensive data indicates that the land are is used for social and customary rights which are recognized as collective rights of local communities (a.k.a communal rights) by the law state. It is often dominated by large employers, therefore it also always lead to social conflict that would hinder efforts to empower the community. It is a very strategic and needs to be revisited in the term of arrangement, surveying, mapping and land use through spatial planning. Through the correct land, stewardship will implement possession, use and utilization of land, therefore it produces a map of community of land ownership which is in accordance with the statement of Mozumdar (2012). Mozumdar (2012) stated that the government of food deficit developing countries should reform the traditional agricultural policies and formulate new appropriate policies emphasizing the non-conventional production factors that can promote them to increase the production capacity agriculture through productivity growth and thereby improving the food security.

The live and livelihood of people in Kampar depend on the agricultural sector. Land utilized for agriculture is a productive asset in the effort to improve the welfare of farmers. The difficulty of the land needs for agricultural areas is dominated by the company in which Cultivation Rights Title in Kampar causing land values should continue to rise. On the other hand, land administration system which is still weak will cause land frequent and disputes problems arise in the society. Total issuance of certificates of Freehold title of year-to-year was declined. In 2006, there were 5.172 issuance of Freehold Title. In 2009, there were 1,489. However, since 2006, there were no issuance for Cultivation Rights Title while in 2009 there were 12 issuance of the Cultivation Rights Title.

In an attempt to overcome various problems of poverty that exist in Kampar regency for 5 (five) years, Kampar District Government has made several breakthroughs in the form of programs / activities, both short term and long term. The agricultural sector which include food crops, horticulture, livestock, crops, fisheries and forestry play a major role in the provision of food to support food security in the region fulfill the right to food and earner of foreign exchange and GDP.

Kampar district's geography is a potential land for agricultural development. Nonetheless, Kampar still faced by a decline in the production of rice and pulses that affect the rice shortage. It's because the management of land resouces are not optimal yet. In related to the policy of agricultural development, wetlands, fields and dry land must be adapted to the paradigm of agricultural development and revitalization functions supported synergistically to develop a network of agri-food crops and horticulture. 


\section{CONCLUSION}

1) The geographic condition of Kampar is a potential land for the development of food crops. Nevertheless, this region still faced by the decline in the production of rice and pulses that have an impact on rice shortage. It's because the management of land resouces are not optimal yet. In addition, the land conditions located in the region of red organosol land and yellow podzolic which are less fertile cause an increased difficulty in improving productivity. Furthermore, the existence of climate change due to global warming causes frequent extreme weather impact on cropping patterns, damaging plants. It also relates to the agricultural development policies either wetlands, swamps and dry land which have not been adapted to the paradigm of agricultural development. The development itself is supported by synergistic and revitalization functions network to develop the agri-food crops and horticulture;

2) The potential dry lands in Kampar regency are quite extensive, which are already used by communities to live their daily lives. But there are still a lot of dry land that has not been utilized, especially in District Tapung Tapung Hulu and Hilir. Seen from the percentage of utilization, the dry land area has not been utilized and amounted to 48 percent of dry land utilized, while the rest of 52 percent not yet utilized. This condition would increase the amount of production of the commodity in the growing by the community. A touch of education is currently perceived less effective to encourage farmers to make improvements cultivation technology.

3) Due to the increasing number of people since 2010, demand for rice in Kampar has increased, ie 75669.11 tonnes, while rice production is only 62535.5142899 .36 tons, equal to tons of rice. This condition has caused the deficit need in that area as much as 32769.75 tons or $40.31 \%$ of rice. Likewise, other food such as nuts is also in a state of deficit as much as 5331.12 tons or $68.77 \%$. An effort to boost the number of rice production is to increase the area of planting. These conditions should be further conducted, because there are many areas that have not been utilized, such as in District Tambang, where the vast untapped area is 1,015 hectares. Most farmers do not want to make the effort to expand the planting area because of low income. It causes less interest from farmers to make the use of cultivation technology innovation and improve productivity. Currently rice productivity are still in the state of 3.6 tons per ha; 2.2 tons per ha of corn and 1.1 tons per ha of soybeans;

4) Although some vacant lands have been planted with a wide variety of crop, but in reality not all of these plants can be harvested. This is due to some kind of crop damage / failure caused by a variety of factors, ranging from pests, less fertilizer to the crop failure caused by flooding. If you have been discussing about the acreage and harvested area, the end result is certainly the amount of production. If in view of the number of crop production in this area over a span of five years, also fluctuated;

5) The life and livelihood for the majority of people in Kampar depend on the agricultural sector. Land utilized for agriculture is productive asset in the effort to improve the welfare of farmers. The difficulty of the land needs for agricultural areas and dominate by the company which Cultivation Rights Title in Kampar causing land values continue to rise. On the other hand, land administration system which is still weak cause land frequent and dispute problems arise in the society;

6) Farmland, the number of seeds, fertilizers, insecticides and labor significantly and simultaneously influence the food security. Farmland, the number of seeds and fertilizers partially have significant effect, but insecticides and labor have no significant effect on the resistance of Kampar regency, Riau. The difficulty of the land needs for agricultural areas will threaten food security in Kampar, Riau.

\section{REFERENCES}

BPS, 2013. Riau Dalam Angka 2011. Kerjasama Bappeda Provinsi Riau dan BPS, Pekanbaru

CBS, 2013. Statistik Perdagangan Luar Negeri Provinsi Riau Menurut Kabupaten/Kota tahun 2009. BPS Provinsi Riau Pekanbaru.

CGIAR. The Consultative Group on International Agricultural Resesarch. 2009. Climate agriculture and food security: A strategy for change. December.

Gevisioner, 2014, Potret Permasalahan Ketahanan Pangan di Provinsi Riau, Artikel BKP-Riau, Pekanbaru.

Du Toit, D. C.; M.D. Ramonyai; P.A. Lubbe and . Ntushelo. 2011. Food Security by Directorate Economic Services. Production Economics Unit. Department Agriluure, Forestry and Fisheries. Republic of South Africa. March.

Essex Jamey. 2010. Sustainability, Food Seccurity, and Deelopment Aid after the Food Crisis: Assesing Aid Strategies across Donor Contexts. Sustainability. 2. 3354-3382. October.

Isyandi. 2005. Menggesa dan Gejolak Perekonomian Indonesia : Memasuki era Otonomi Daerah dan Globalisasi, Unri Press Pekanbaru

Isyandi dan Kawan-kawan, 2007, Mapping Potensi Ekonomi Propinsi Riau dan Kepulauan Riau, FEUnri dan Bank Riau, Pekanbaru.

Mehra, Rekha and Mary Hill Rojas. 2008. Women, Food Security and Agriculture in a Global Market Place. International Center for Research on Women. Mosher, T.J., Dardzinski, B.J. and Smith, M.B., 2000. 
Human Articular Cartilage: Influence of Aging and Early Symptomatic Degeneration on the Spatial Variation of T2-Preliminary Findings at 3 T 1. Radiology, 214(1), pp.259-266.

Mozumdar, Lavlu. 2012. Agricultural Productivity and
Food Security in Developing World. Bangladesh Journal of Agricultural Economics. XXXV, 1 \& $2,53-69$.

Sugiyono. 2009. Uma Sekaran, 2006, Metodologi Penelitian Bisnis, Penerbit Alfabeta. Bandung. 